BUILDING TECHNOLOGY 
By the same author

Advanced Building Measurement

Building Economics, Third edition

Building Maintenance

Building Quantities Explained, Third edition

Building Surveys, Reports and Dilapidations

Civil Engineering Con tract Administration and Control

Civil Engine ering Quantities, Third edition

Civil Engineering Specific ation, Second edition

Local Government Explained

Municipal Engineering Practice

Outdoor Recreation and the Urban Environment

Planned Expansion of Country Towns

Quantity Surveying Practice 


\section{BUILDING TECHNOLOGY}

\section{IVOR H. SEELEY \\ BSc (Est Man), MA, PhD, FRICS, \\ CEng, FICE, MCIOB}

Emeritus Professor of Trent Polytechnic, Nottingham

Third Edition

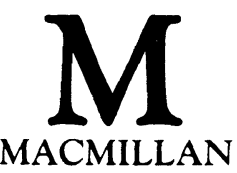


() Ivor H. Seeley $1974,1980,1986$

Reprint of the original edition 1986

All rights reserved. No reproduction, copy or transmission of th is publication may be made without written permission.

No paragraph of this publication may be reproduced, copied or transmitted save with written permission or in accordance with the provisions of the Copyright Act 1956 (as amended).

Any person who does any unauthorise d act in relation to this publication may be liable to criminal prosecution and civil claims for damages.

First edition 1974

Reprinted 1975, 1976, 1977, 1978, 1979

Second edition 1980

Reprinted 1981, 1982, 1983, 1985

Third edition 1986

Published by

MACMILLAN EDUCATION LTD

Houndmills, Basingstoke, Hampshire RG21 2XS

and London

Companies and representatives

th rough out the world

British Library Cataloguing in Publication Data

Seeley, Ivor $\mathrm{H}$.

Building technology.-3rd ed.

(Macmillan building and surveying series)

1. Building

I. Title

690 TH145

ISBN 978-0-333-43350-8 ISBN 978-1-349-09223-9 (eBook) DOI 10.1007/978-1-349-09223-9

Series Standing Order

If you would like to receive future tiltles in this series as they are published, you can make use of our standing order facility. To place a standing order please contact your bookseller or, in case of difficulty, write to us at the address below with your name and address and the name of the series. Please state with which title you wish to begin your standing order. (If you live outside the United Kingdom we may not have the rights for your area, in which case we will forward your order to the publisher concerned.)

Customer Services Department, Macmillan Distribution Ltd Houndmills, Basingstoke, Hampshire, RG21 2XS, England. 
This book is dedicated to my wife for her continual interest in building matters and for producing such a good design for our bungalow, where some of the constructional methods described in the book have been put into practice 


\section{CONTENTS}

List of illustrations

List of tables

Preface to the third edition

\section{Acknowledgements}

\section{THE BUILDING PROCESS AND SITEWORKS}

Choice of site; site investigation; groundwater drainage; setting out; control of building work; sequence of building operations; problems in design and construction of buildings.

\section{BUILDING DRAWING}

Drawing instruments and materials; layout and presentation of drawings; sketches; working drawings.

\section{FOUNDATIONS}

Identification and characteristics of soils; design of foundations; foundation types and their selection; excavation and trench timbering; concrete; cements; aggregates; site testing of materials; concrete mixes; concreting operations; reinforced concrete; prestressed concrete; basement construction.

\section{WALLS}

Functions of walls; bricks and blocks; mortars; building brick and block walls; cavity walls; cavity wall insulation; damp-proof courses; scaffolding; arches and lintels; external treatments to walls; stone walls; crosswall construction; nontraditional housing; timber frame construction; internal partitions.

\section{WINDOWS}

General principles of window design; woodcasement windows; double-hung sash windows; defects in wood windows; metal windows; glass and glazing; double glazing and double windows; patent glazing.

\section{DOORS}

General principles of design of doors; door types; door frames and linings; metal doors; ironmongery.

\section{STAIRS AND FITTINGS}

Staircase design; timber staircase construction; stairways in other materials; wood trim; simple joinery fittings; panelling. 


\section{FINISHINGS}

Internal wall finishings; internal ceiling finishings; external renderings; painting.

12 WATER SERVICES AND SANITARY PLUMBING

Cold water supply; hot water supply; sanitary appliances; sanitary pipework above ground; lowpressure hot-water central heating systems.

\section{DRAINAGE}

Design of drains; choice of pipes; pipe laying; drainage layout; interceptors; manholes and inspection chambers; testing of drains; cesspools; small domestic sewage treatment works.
Road design, road construction; road drainage; footpaths and paved areas; landscape work; fencing; gates.

\section{BUILDING IN WARM CLIMATES}

Factors influencing overseas building; design of buildings for warm climates; construction of buildings in warm climates; behaviour of building materials; special structural problems.

Appendix: Metric conversion table

Index 


\section{LIST OF ILLUSTRATIONS}

Figure 1.1 Ground-water drainage

Figure 1.2 Setting out

Figure 2.1 Drawing instruments

Figure 2.2 Presentation of drawings

Figure 2.3 Styles of lettering and working drawings

Figure 2.4 Isometric and axonometric projections

Figure 3.1 Minirnum width of strip foundations

Figure 3.2

Figure 3.3

Figure 3.4

Figure 4.1

Figure 4.2

Figure 4.3

Figure 4.4

Figure 4.5

Figure 4.6

Figure 4.7

Figure 4.8

Figure 5.1

Figure 5.2

Figure 5.3

Figure 5.4

Figure 6.1

Figure 6.2

Figure 6.3

Figure 6.4

Figure 6.5

Figure 7.1

Figure 7.2 TRADA timber roof trusses and trussed rafters

Figure 7.3 Timber and steel roof trusses

Figure 7.4 Trimming pitched roof aro'snd chimney stack

Figure 7.5 Roof tiling
Figure 7.6 Roof slating and asbestos cement sheeting

Figure 7.7 Timber and concrete flat roofs $\quad 127$

Figure 7.8 Lead flat roofs 129

Figure 7.9 Zinc and copper flat roofs 130

Figure 8.1 Wood casement windows and open space requirements

Figure 8.2 Inward-opening, pivoted and bullseye wood windows

Figure 8.3 Double-hung sash windows

Figure 8.4 Metal windows, double glazing and double windows

Figure 9.1 Panelled and glazed doors $\quad 152$

Figure 9.2 Panelled door details 153

Figure 9.3 Flush door details 154

Figure 9.4 Door frames and linings 156

Figure 9.5 Door ironmongery 158

Figure 10.1 Design of timber staircases $\quad 162$

Figure 10.2 Timber staircase details 165

Figure 10.3 Stairs in alternative forms and wood trim 168

Figure 10.4 Kitchen fitments 170

Figure 10.5 Built-in wardrobes and panelling 171

Figure 12.1 Cold water supply 185

Figure 12.2 Hot water supply and soil appliances $\quad 188$

Figure 12.3 Sanitary appliances 193

Figure 12.4 Sanitary pipework above ground and low pressure hot water central heating systems

Figure 13.1 Drain laying, jointing and protection 201

Figure 13.2 House drainage layout, intercepting chamber and petrol interceptor details 205

Figure 13.3 Manholes and inspection chambers 208

Figure 13.4 Cesspools and small domestic sewage treatment works

Figure 14.1 Roads and footways 215

Figure 14.2 Fencing and gates 


\section{LIST OF TABLES}

Table 2.1 Recommended scales $\quad 16$

Table 3.1 Soil identification 25

Table 3.2 Typical bearing capacities of soils 28

Table 3.3 Choice of foundation 32

Table 3.4 Grades of concretes 37

Table 4.1 $\begin{aligned} & \text { Suitable mortar mixes for various unit } \\ & \text { strengths }\end{aligned}$

Table 4.2 Exposed walls: minimum insulation thickness 46

Table 4.3 Mortar mixes (proportions by volume) 53

Table 4.4 Selection of mortar groups 53

Table 4.5 Materials for damp-proof courses 64

Table 6.1 Timbers in common use 103

Table 7.1 Minimum slopes for pitched roof coverings 119

Table 7.2 Calculation of drained roof area 131

Table 7.3 Gutter sizes and outlets sizes 131

Table 11.1 Characteristics of plaster finishes $\quad 174$

Table 11.2 Mixes suitable for rendering $\quad 179$

Table 11.3 Recommended mixes for external renderings in relation to background materials, exposure conditions and finish required

Table 13.1 Maximum spacing of access points to drains in metres

Table 13.2 Minimum internal dimensions for manholes and inspection chambers

Table 14.1 Comparison of constructional methods for roads

Table 14.2 Comparison of constructional methods for footpaths

Table 15.1 Thermal capacity and insulation requirements

Table 15.2 Factors affecting the performance of building materials in warm climates 


\section{PREFACE TO THE THIRD EDITION}

This book examines the general principles of building construction and applies them to practical examples of constructional work throughout all parts of simple domestic buildings. Consideration is also given to the choice of materials and implications of Building Regulations, British Standards, Codes of Practice and current government research.

The principal aim is to produce a comprehensive, simply explained and well-illustrated text which will form a basic construction textbook for first- and second-year students in a variety of disciplines, including architects, quantity surveyors, valuers, auctioneers, estate agents, building and mineral surveyors, builders, housing managers, environmental health officers, building control officers and clerks of works. It should also prove of value to those working for BTEC certificates and diplomas in construction; degrees in architecture, building, quantity surveying and estate management; and the General Certificate of Education in building construction.

All drawings and building data are fully metricated, and it was decided to omit ' $m$ ' and ' $m m$ ' symbols from all descriptions as well as dimensions on the drawings, to avoid constant repetition of units of measurement. It is unlikely that any confusion will arise as a result of this. A metric conversion table is produced in an appendix to help readers who wish to make comparisons between imperial and metric measures. The abbreviations BRE, for Building Research Establishment, and DOE, for Department of the Environment, have been used extensively throughout the book.

This third edition has been considerably extended and updated to include latest developments, including the requirements of the Building Regulations 1985 and their application. A new chapter has been added covering the principal problems encountered, and the building techniques and materials used in warm climates, which it is hoped will be of value to readers both in the United Kingdom and overseas.

IVOR H. SEELEY 


\section{ACKNOWLEDGEMENTS}

THE author acknowledges with gratitude the willing co-operation and assistance received from many organisations connected with the building industry - manufacturing, research and contracting.

The Controller of Her Majesty's Stationery Office has given permission to incorporate extracts from The Building Regulations 1985, and supporting Approved Documents (Crown Copyright). Crown copyright material is also reproduced from BRE Digests and other publications, by permission of the Director of the Building Research Establishment; in this connection it should be mentioned that copies of the digests quoted are obtainable from the Building Research Establishment, Garston, Watford, Herts WD2 7JR, and Building Centres.

Extracts from British Standards and Codes of Practice are reproduced by permission of the British Standards Institution, Linford Wood, Milton Keynes, MK14 6LE. The Institution allows a discount on sales of publications to students and educational bodies and BS Handbook 3 contains useful summaries of British Standards for building, which are updated periodically.

The quality and usefulness of the book has been very much enhanced by the large number of first-class drawings which do so much to bring the subject to life. Ronald Sears devoted many hundreds of hours to the painstaking preparation of the final drawings, for which he deserves special appreciation. The author also expresses his gratitude to the publishers, for their continual assistance throughout the production of the book. Thanks are due to those readers who wrote to the author with helpful comments, and to Charles Hardwick of Trent Polytechnic Library for his prompt and valuable assistance. 